\title{
Strategi Komunikasi Persuasif Petugas Kementerian Agama Kabupaten Aceh Tamiang Dalam Memberikan Informasi Pembatalan Ibadah Haji 2020-2021 Pada Calon Jamaah Haji
}

\author{
Masriadi $^{1}$, Kamaruddin Hasan ${ }^{2}$, Cut Andyna ${ }^{3}$, Rinjani Bahri ${ }^{4}$ \\ ${ }^{1-4}$ Dosen Ilmu Komunikasi, Fakultas ISIP, Universitas Malikussaleh (Unimal), Aceh Utara. \\ Penelitian didanai PNBP Universitas Malikussaleh, Aceh Utara, 2021 \\ Email :dimas@unimal.ac.id
}

\begin{abstract}
The persuasive communication strategy of Kementerian Agama RI Kabupaten Aceh Tamiang to convey information to prospective pilgrims (CJH) is carried out in two formats, namely face-to-face and the use of conversation applications. In this study, the theoretical basis, concepts and models used were the AIDDA (Attention, Interest, Desire, Decision, Action) model. This study uses qualitative research methods so that it can be seen the persuasive communication strategies carried out by hajj officers in Aceh Tamiang Regency. The number of prospective Hajj pilgrims in 2020 is 112 people. However, due to the Covid19 pandemic, the pilgrimage was canceled due to fears that the virus known as the corona virus would spread. The cancellation of the hajj gave rise to rumors that Indonesia was experiencing a budget crisis and the hajj money had been used to deal with the impact of the Covid-19 pandemic. Thus, out of 112 prospective pilgrims, one person was asked to withdraw their funds. To explain to prospective pilgrims, four meetings were held throughout 2020 and 2021 for prospective pilgrims, religious leaders and important figures in Aceh Tamiang. Thus, prospective hajj pilgrims and the public will receive accurate information about the cancellation of hajj and the mechanism for withdrawing hajj funds.
\end{abstract}

Keywords : Strategy; Persuasive Communication; Information;

\begin{abstract}
Abstrak: Strategi komunikasi persuasif petugas Kementerian Agama RI Kabupaten Aceh Tamiang untuk menyampaikan informasi pada Calon Jamaah Haji (CJH) dilakukan dalam dua format yaitu tatap muka dan penggunaan aplikasi percakapan. Dalam penelitian ini menggunakan pijakan teori, konsep dan model digunakan model AIDDA (Attention, Interest, Desire, Decision, Action ). Penelitian dilakukan dengan pendekatan kualitatif agar dapat diketahui strategi komunikasi persuasif yang diimplementasikan oleh petugas penyelenggara ibadah haji Kabupaten Aceh Tamiang. Jumlah calon jamaah haji tahun 2020 sebanyak 112 orang. Namun, karena pandemi Covid-19, terjadi pembatalan ibadah haji karena dikhawatirkan terjadi penyebaran virus yang dikenal dengan sebutan corona tersebut. Pembatalan ibadah haji ini melahirkan isu bahwa Indonesia mengalami krisis anggaran dan uang ibadah haji telah digunakan untuk menangani dampak pandemi Covid-19. Sehingga, dari 112 calon jamaah haji, satu orang diantanya menarik dana tersebut. Untuk menjelaskan pada calon jamaah haji, digelar pertemuan empat kali sepanjang tahun 2020 dan 2021 untuk calon jamaah haji, tokoh agama dan tokoh kunci di Aceh Tamiang. Sehingga, calon jamaah haji dan masyarakat menerima informasi yang akurat tentang pembatalan ibadah haji dan mekanisme penarikan dana haji.
\end{abstract}

Kata kunci : Strategi; Komunikasi Persuasif, Informasi

\section{Pendahuluan}

Komunikasi adalah salah satu aspek bagi kehidupan manusia yang paling mendasar. Dalam menjalani proses kehidupannya, manusia menempatkan komunikasi pada posisi yang sangat penting. Komunikasi yaitu suatu proses dalam penyampaian makna dari satu entitas/kelompok atau kekelompok yang lain dengan tujuan saling mempengaruhi diantara keduanya. Berdasarkan paradigma Harold Laswell, komunikasi memiliki 5 (lima) unsur atau komponen yang lebih dikenal dengan istilah "Siapa Berkata Apa Pada Media Apa Kepada Siapa dengan Efek Apa" Adapun 5 (lima) elemen dasar itu yakni Who yang berarti 
komunikator, Says berarti pesan, in Which Channel berarati media/saluran yg digunakan, to Whom artinya kepada siapa atau komunikan, dan With What Effect artinya Efek atau dampak yang ditimbulkan. Lima unsur tersebut dapat membantu para komunikator dalam menjalankan tugasnya menyampaikan informasi (Wiryanto, 2004).

Efektif tidaknya suatu proses komunikasi sangat bergantung kepada 5 (lima) unsur tersebut dimana kesemuanya saling mempengaruhi satu dan lainnya. Dalam mempengaruhi penerima pesan (komunikan), komunikator bertindak sesuai dengan stimulus yang didapat. Tujuannya untuk merubah sikap dan perilaku dari si penerima pesan (komunikan) (Mulyana, 2005). Elemen dasar komunikasi tersebut yaitu komunikator, pesan, media, harus memiliki metode, teknik atau strategi tertentu dalam merubah sikap dan perilaku komunikan. Terdapat beberapa strategi dan teknik komunikasi yang digunakan dalam mempengaruhi komunikan. Salah satunya adalah menggunakan komunikasi persuasif.

Persuasif merupakan suatu usaha yang dilakukan oleh komunikator dengan kredibilitas tertentu untuk mengubah sikap/ perilaku dari komunikan dengan penyampaian pesan yang baik (Zain, 2017). Komunikasi persuasif juga dapat digunakan dalam berbagai bentuk kegiatan komunikasi termasuk juga dalam berbagai proses pembinaan dan kegiatan pelatihan termasuk dalam penyelenggaraan manasik haji. Haji merupakan bagian rukun Islam ke-5 dimana hukumnya wajib untuk seorang muslim yang mampu. Namun tidak semua muslim wajib untuk menjalankan ibadah Haji ini, dikarenakan ibadah ini kewajiban yang memerlukan aspek kesehatan khususnya jasmani yang prima serta adanya kesanggupan keuangan (Syaikh Abdul Aziz bin Abdullah, 2003) (Prasetyo, 2017).

Di era globalisasi yang berkembangnya teknologi informasi seperti sekarang ini, masyarakat senantiasa menuntut untuk memperoleh pelayanan yang berkualitas diberbagai sektor kehidupan, demikian pula dengan pelayanan dalam bimbingan haji kepada para jamaah. Pelayanan ini mencakup beberapa hal yaitu mulai dari proses persiapan pendaftaran jamaah haji, kegiatan manasik hingga keberangkatan ke tanah suci. Makna sosial yang terkandung dari ibadah haji adalah para jamaah haji memiliki pengetahuan untuk menerapkan nilai dan ajaran dalam Islam yang dilaksanakan selama haji ke dalam kehidupan sosial sepulang dari tanah suci. Indonesia memiliki mayoritas penduduk beragama Islam, maka banyak individu yang berkeinginan untuk melaksanakan ibadah haji. Hal ini mengakibatkan individu yang ingin menunaikan ibadah haji harus mendaftar terlebih dahulu, kemudian agar dapat berangkat calon jamaah mesti menunggu dalam kurun waktu kurang lebih 20 atau sampai dengan 30 tahun bahkan lebih tergantung kuota daerah yang berlaku. Kehadiran program dana talangan yang disediakan banyak pihak bank, menambah panjang daftar antrian calon jamaah haji.

Setiap tahunnya antusiasme umat yang ingin menunaikan ibadah haji kian meningkat. Ini tentunya menyebabkan panitia penyelenggaraan ibadah haji kewalahan dalam mengatur dan mengelolanya. Konsekuensinya tentu terhadap kualitas pada aspek pelayanan dan juga perlindungan terhadap calon jamaah haji sehingga dipandang kurang efektif dan efisien. Bahkan kemungkinan terjadinya penyimpangan motivasi, sikap ikhlas dan juga kesabaran dari calon jamaah Haji semakin besar. Dalam sejarahnya, penyelenggaraan aktifitas ibadah haji di Indonesia sampai hari ini senantiasa dihadapkan pada berbagai persoalan yang tidak kunjung selesai. Aspek penyelenggaraannya sering dihadapkan pada soal-soak klasik, seperti 
peningkatan calon jamaah tiap tahunnya tetapi tidak dibarengi dengan peningkatan pada kualitas pelayanan.

Bagi calon jamaah haji merupakan ibadah yang menuntut kesiapan dalam hal penguasaan materi yang diperoleh dalam manasik haji, kesehatan fisik yang prima, kesiapan mental calon jamaah, kesabaran, kemampuan berbahasa Arab serta ketakwaan. Hal ini tentu diperlukan karena letak geografis antara Indonesia dengan Arab Saudi cukup jauh. Menunaikan ibadah haji adalah anjuran bagi yang mampu melaksanakannya. Namun, pada pelaksanaannya terkadang berbenturan dengan berbagai hal, seperti minimnya pengetahuan calon jamaah dan cara pelaksanaannya. Dengan demikian maka calon jamaah harus diberikan pengetahuan yang memadai berkenaan dengan pelaksanaan ibadah haji.

Menurut (Undang-Undang Republik Indonesia No. 13 Tahun 2008 Tentang Penyelenggaraan Ibadah Haji, 2008) mengisyaratkan terkait aturan dan juga tata laksana Ibadah Haji bagian dari tugas Negara dalam hal ini jadi tanggung jawab melalui Kementerian Agama dengan bekerjasama dengan masyarakat, serta instansi terkait lainnya. Dalam memenuhi implementasi dari UU di atas maka wajib bagi Pemerintah melakukan pembinaan kepada jamaah haji sejak tahap persiapan keberangkatan, ketika tiba di Arab Saudi hingga balik ke Indonesia. Hal ini sebagai upaya bentuk peningkatan dalam aspek pelayanan penyelenggaraan Ibadah Haji dan tentunya agar mendapatkan kelancaran, ketertiban, kesejahteraan dan keselamatan para jamaah dan tentu menjadi bagian dari kesempurnaan pelaksanaan haji, maka Pemerintah dalam konteks ini melalu Kementrian Agama Kabupaten Aceh Tamiang berkewajiban untuk melakukan pembinaan kepada para jamaah untuk mengikuti kegiatan manasik haji kepada Calon Jamaah Haji.

Regulasi tersebut pula menjelaskan bahwa keterbukaan informasi harus disampaikan kepada calon jamaah haji. Namun, ditahun 2020 dan 2021, menyusul pandemi Covid-19 di seluruh negara, Indonesia tidak memberangkatkan jamaah haji. Kebijakan ini menjadi polemik karena sebagian warga tidak percaya akan pemerintah. Dana haji menjadi polemik di Indonesia. Sebagian calon jamaah haji memutuskan untuk menarik kembali dana haji mereka yang telah disetorkan ke Badan Penyelenggara Ibadah Haji (BPIH) sebagai bentuk ketidakpercayaan pada pemerintah. Masyarakat menduga dana haji digunakan untuk infrastruktur, sehingga tidak bisa memberangkatkan jamaah haji dua tahun terakhir. Kondisi ini menjadi masalah utama dalam penelitian ini. Sehingga diperlukan strategi komunikasi persuasif dalam menjelaskan kegagalan pembatalan ibadah haji tahun 2020 dan 2021 di Kabupaten Aceh Tamiang. Maka tulisan ini akan Strategi Komunikasi Persuasif Petugas Kementerian Agama Kabupaten Aceh Tamiang Dalam Memberikan Informasi Pembatalan Ibadah Haji 2020-2021 Pada Calon Jamaah Haji.

\section{Landasan Teori}

\section{Komunikasi Persuasif}

Komunikasi adalah aktivitas keseharian manusia dalam menjalani kehidupan, namun sangat sedikit yang dapat mendefinisikan komunikasi secara memuaskan. Beragam variasi definisi komunikasi muncul seperti konsep saling berbicara satu dan lainnya, penyebaran informasi dan masih banyak lagi. Secara etimologis kata komunikasi dalam bahasa latin communis artinya sama. Komunikasi berarti bahwa terdapat makna pikiran dari sebuah pesan yang dipahami secara bersama (Candrasari \& Naning, 2019) (Alo liliweri, 2011). 
Menurut Alo Liliweri menjelaskan komunikasi memiliki arti menyampaikan pesan berupa ide, perasaan bahkan opini seseorang disampaikan kepada orang lain dengan tujuan mendapatkan jawaban dan tanggapan atau umpan balik (Hafied Cangara, 2008). Sedangkan pengertian komunikasi secara terminologi memili arti sebuah penyataan satu orang kepada orang lain. Secara paradigmatis, dapat dikatakan komunikasi juga sebagai proses dalam menyampaikan sebuah pesan untuk menginformasikan juga mengubah pendapat, sikap dan perilaku orang lain baik langsung dalam bentuk lisan atau tulisan melalui sebuah media (Onong Uchjana Effendy, 2005). Produk utama dari proses komunikasi adalah pesan. Pesan adalah simbol yang digunakan untuk menyampaikan gagasan ide, pikiran dan perasan dalam bentuk tulisan, kata, gambar, gerak tubuh, benda, tingkah laku dan bentuk tanda lainnya. Komunikasi bisa terjadi dalam diri seseorang, kemudian antar dua orang, beberapa orang hingga orang yg lebih banyak. Tujuan komunikasi dilakukan tentunya sesuai dengan kepentingan masing-masing orang.

Melalui beberapa definisi tersebut maka disimpulkan komunikasi ialah proses dalam menyampaikan sebuah pesan dari komunikator dalam bentuk lambang / simbol akan suatu ide, informasi dan gagasan lainnya dalam upaya merubah pendapat, sikap dan perilaku komunikan melalui media tertentu.

Sementara persuasif menurut Sastroepoetro adalah kata persuasi sendiri asal katanya persuation dari kata kerja to persuade artinya membujuk, menghimbau dan merayu. Merangsang seseorang untuk melakukan sesuatu dengan spontan dan sukarela tanpa dipaksa (Suranto AW, 2011). Sehingga persuasif bisa diartikan upaya untuk mempengaruhi serta mengendalikan perilaku orang lain dengan cara pendekatan psikologis (F. Rachmadi, 1993). Sedangkan pengertian yang lebih rinci persuasif adalah upaya merubah sikap manusia dengan memberikan ide, pikiran, pendapat juga fakta-fakta baru lewat pesan pesan yang komunikatif (Hanana et al., 2017).

Jika dilihat dari pengertian kedua kata tersebut, maka dapat didefinisikan sebagai suatu kegiatan komunikasi yang dilakukan secara persuasif yaitu mengandung ajakan maupun himbauan. Aktifitas ini berusaha merangsang dan mendorong seseorang untuk berbuat sesuatu seperti yang dikehendaki. Komunikasi persuasif ialah komunikasi yang memiliki sifat mempengaruhi audience untuk bertindak sesuai yang diharapkan oleh komunikator. Persuasif adalah suatu bentuk komunikasi yang paling mendasar untuk mendefeniskan perubahan sikap karena paparan informasi dari orang lain (Warner J. Severin dan James W. Tankard, 2009).

\section{Teknik Komunikasi Persuasif}

Upaya mengubah sikap serta perilaku komunikan memerlukan teknik yang tepat. Seorang komunikator harus mampu memprediksi hasil yang akan dicapai dan mengetahui siapa komunikan serta memahami keadaan komunikan. Keberhasilan suatu proses komunikasi tentunya dari kemampuan dalam membujuk orang lain agar mengikuti apa yang kita inginkan, inilah yang dimaksudkan dengan persuasif. Kemampuan persuasi berarti upaya agar terjadi perubahan pendapat hingga sikap karena adanya informasi dari orang lain. Komunikasi persuasif memiliki tujuan mengubah pendapat serta sikap hingga perilaku dari lawan bicara kita dengan pendekatan psikologisnya. Hal ini agar pendapat, sikap dan perilaku seseorang berubah secara perlahan dan mengedepankan aspek kesadaran hingga perubahan 
pada hal kemauan yang disertai perasaan senang. Persuasif meyakinkan pengaruh kepada orang lain agar pesan diterima dengan baik dan terjadinya perubahan pada tindakan sesuai yang diinginkan oleh pengirim pesan.

Komunikasi persuasive memiliki beberapa unsur penting yaitu : terdapat model, perubahan maupun penguatan tanggapan yang meliputi sikap, emosi, kemauan dan perilaku. Jadi dapat disimpulkan bahwa komunikasi persuasif menekankan pada pendekatan personal, bersifat ajakan, tidak memaksa agar komunikasi mengubah sikapnya sesuai dengan apa yang diharapkan komunikator dengan penuh kesadaran. Indikator komunikasi persuasif dari pengertian di atas yaitu memberikan pesan yang positif, konstruktif, responsif, kritis, menghargai orang lain, keakraban, dan meyakinkan.

Diperlukan perencanaan yang baik agar komunikasi persuasif mencapai tujuannya yaitu dengan menggunakan unsur-unsur ilmu komunikasi seperti komunikator yang baik, isi pesan yang mendukung motif, media dan komunikan. Biasanya teknik ini efektif, komunikan tidak hanya tahu, tetapi kemudian menjadi tergerak.

\section{Tahapan dan Perencanaan Komunikasi Persuasif}

Komunikasi persuasif dimulai dari menerapkan cara yang manusiawi serta halus agar lawan bicara bisa menerima dan melakukan secara sukarela sesuai dengan maksud pesan yang disampaikan. Misalnya, seorang guru berkomunikasi tentu menggunakan cara yang fleksibel dengan pendekatan kemanusiaan. Keberhasilan komunikasi persuasif ada tahapan yang perlu diperhatikan. Menurut Onong U. Effendi tahap ini dikenal dengan prosedur A-A procedure atau form attention to action procedure melalui rumus AIDDA yang merupakan singkatan dari Attention (perhatian), Interest (minat), Desire (keinginan), Decision (keputusan) dan Action (tindakan).

1. Attention (Perhatian): Tahap dimana komunikator harus mampu membuat komunikan yakin di awal bahwa komunikator memiliki sesuatu yang penting dan berguna untuk didengarkan. Memperkenalkan komunikasi pada masalah atau ide yang akan membuat mereka ingin mendengarkan pesan anda.

2. Interest (Minat): Tahap dimana komunikator menjelaskan relevansi pesan kepada komunikan. Pernyataan-pernyataan yang disajikan sebelumnya kemudian dikembangkan secara lebih rinci. Tujuannya adalah bagaimana komunikan bisa berpikir. Menghubungkan pesan yang ingin disampaikan dengan manfaat tertentu yang dapat dinikmati oleh audiens.

3. Desire (Hasrat): Pada tahap inilah komunikator audiens mengubah keinginannya dengan menjelaskan bagaimana perubahan yang akan dilakukan nantinya dapat memberikan manfaat yang lebih baik bagi audiens. Memastikan bahwa bukti apa pun akan digunakan untuk membuktikan gagasan secara langsung dan relevan dengan subjek.

4. Action (Tindakan): Fase terakhir ini komunikator menyarankan tindakan spesifik yang diinginkan komunikator untuk dilakukan oleh audiens. Kemudian perlu diingatkan kembali bahwa penonton akan mendapatkan keuntungan dari tindakan yang akan dilakukan. Yang penting yaitu betapa mudahnya penonton melakukan aksinya.

Berdasarkan rumus AIDDA, upaya mendapatkan perhatian merupakan bagian penting dalam komunikasi persuasif. Menggunakan kata-kata yang menarik juga didukung dengan 
gaya penampilan (performance) yang menarik simpatik komunikan. Setelah komunikator berhasil membangkitkan perhatian komunikan, langkah selanjutnya adalah tahap menumbuhkan minat komunikan. Setelah komunikator berhasil membangkitkan minat, langkah selanjutnya adalah menciptakan keinginan dengan cara-cara alternatif, seperti dengan melakukan ajakan atau bujukan. Pada tahap ini perlu ditampilkan daya tarik emosional oleh komunikator agar pada tahap selanjutnya komunikan dapat segera mengambil keputusan untuk melakukan suatu tindakan atau perubahan seperti yang diharapkan oleh komunikator.

\section{Metode}

Penelitian ilmiah adalah suatu pendekatan yang mampu untuk menemukan pengetahuan baru ataupun kebenaran, menguji suatu teori, menjawab pertanyaan atau menemukan masalah yang dihadapi. Oleh karenanya untuk mendapatkan hasil penelitian yang baik dengan harapan, penelitian harus sistematis, logis, skeptis, teliti dan objektif. Jadi pendekatan proses pengumpulan data merupakan syarat utama melakukan penelitian (Sumarsono, 2004).

Metode yang digunakan pada penelitian ini ialah metode deskriptif. Penelitian ini menerapkan paradigma konstruktivisme dengan menggunakan pendekatan kualitatif. Menurut Patton, peneliti konstruktivis harus mempelajari berbagai realitas yang dibangun individu dan implikasi dari konstruksi ini untuk kehidupan mereka dengan orang lain. Penelitian ini dirancang dengan metode penelitian sebagai studi kasus untuk memberikan gambaran yang lebih rinci tentang suatu gejala atau fenomena. Hasil akhir dari penelitian ini biasanya berupa tipologi, aturan, model atau pola mengenai fenomena yang sedang dibahas (Moleong, 2004).

Dalam penggalian informasi dari informan digali secara kualitatif tidak dikuantifikasi dengan perhitungan persentase dan jawaban-jawaban yang sifatnya pasti (fixed question). Penggalian informasi dilakukan secara mendalam dengan perspektif yang mewakili kelompok-kelompok yang dipilih. Dalam assessment informan harus dianggap sebagai subjek yang aktif yang bisa mengembangkan informasi berbasis pertanyaan yang dimunculkan. Makanya untuk keperluan assessment ini, beberapa orang informan saja jika dianggap telah memberikan "gambaran yang mendalam" (thick description) - menggunakan istilah Clifford Geertz-dianggap telah cukup, dibandingkan ratusan responden dari model penelitian kuantitatif.

\section{Hasil Penelitian dan Pembahasan}

\section{Perhatian (attention)}

Pembatalan ibadah haji tahun 2020 dan 2021 dikarenakan pandemi Covid-19 menjadi perhatian serius Kementerian Agama RI dan seluruh calon jamaah haji (CJH) Indonesia. Apalagi sebagai negara yang berpenduduk muslim terbesar di dunia, ibadah haji menjadi salah satu ibadah yang ditunggu-tunggu umat Islam di tanah air. Ketika pandemi Covid-19 mewabah ke seluruh negara, pembatalan pelaksanaan ibadah haji tidak dapat dihindarkan. Dikhawatirkan, pandemi menular lewat kerumunan dalam prosesi pelaksanaan ibadah tersebut. 
Kementerian Agama RI sebagai institusi negara yang mengatur dan menjamin pelaksanaan ibadah haji untuk seluruh umat Islam mengeluarkan Keputusan Menteri Agama RI Nomor. 494 Thn 2020 tentang Pembatalan Keberangkatan Jamaah Haji pada Penyelenggaraan Ibadah Haji Tahun 1441 Hijriah / 2021 Masehi yang ditandatangani pada 02 Juni 2020 oleh Menteri Agama RI yang saat itu dijabat Facrul Razi. Surat keputusan ini sebagai bentuk perhatian serius Kementerian Agama RI tentang kejelasan penyelenggaraan ibadah haji saat pandemi Covid-19 masif melanda negara di seluruh dunia.

Gambar 1

Alur Pengembalian Setoran Pelunasan Bipih bagi Jemaah Haji Reguler

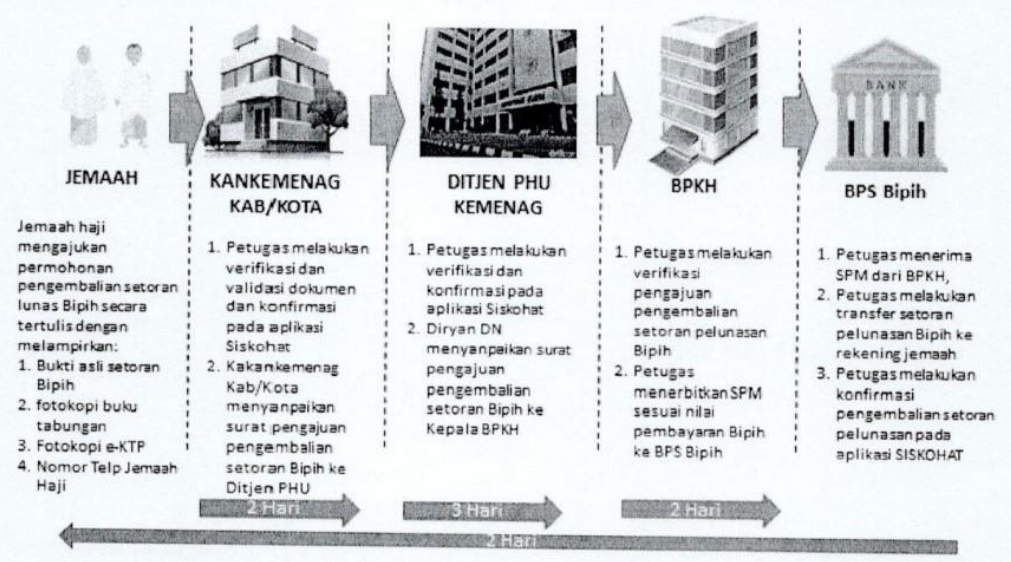

Gambar 1 : Alur Pengembalian Setoran Pelunasan Biaya Perjalanan Ibadah Haji

Secara ekplisit aturan yang dikeluarkan Kementerian Agama RI itu sekaligus menjawab rumors tentang pembatalan ibadah haji karena kas negara digunakan untuk penanganan pandemi. Dalam aturan ini disebutkan rinci jamaah haji boleh mengambil kembali biaya perjalanan yang telah disetorkan ke Kementerian Agama RI.

Khusus untuk Kabupaten Aceh Tamiang total calon jamaah haji sebanyak 112 orang dan yang menarik kembali biaya perjalanan haji hanya satu orang (Wawancara; Kepala Seksi Haji dan Umroh, Kementerian Agama RI Aceh Tamiang, Zakaria, 1 September 2021). Sedangkan calon jamaah haji lainnya tidak melakukan penarikan dana dan menunggu jadwal pemberangkatan setelah pandemi berakhir.

\section{Minat (Interest)}

Setelah memberi perhatian serius pada persoalan pembatalan ibadah haji, Kementerian Agama RI menghadirkan seluruh calon jamaah haji termasuk di Kabupaten Aceh Tamiang pada bulan Agustus dan September 2020. Hal yang sama dilakukan pada tahun 2021 sebanyak dua kali. Pada tahun Pertemuan ini menjelaskan tentang surat Keputusan Menteri Agama RI No. 494 Tahun 2020 tentang Pembatalan Keberangkatan Jamaah Haji Pada Penyelenggaraan Ibadah Haji Tahun 1441 H/ 2021M. Sebanyak 112 orang calon jamaah haji dibagi pada dua pertemuan. Sehingga target penyampaian pesan, calon jamaah haji memahami kondisi pandemi dan alasan pembatalan ibadah haji tahun 2020 dan 2021.

Namun, segmentasi audiens yang dihadirkan pada tahun 2021 sedikit berbeda dibanding tahun 2020. Jika pada tahun 2020 dihadirkan hanya calon jamaah haji yang batal berangkat saja di Kabupaten Aceh Tamiang. Namun, pada tahun 2021, yang dihadirkan termasuk tokoh 
agama seperti Majelis Permusyawaratan Ulama (MPU), Ikatan Da'I Indonesia Aceh Tamiang, dan Forum Remaja Masjid Aceh Tamiang.

Sehingga, informasi tentang pembatalan ibadah haji bisa sampai pada seluruh lapisan masyarakat dalam jumlah yang lebih besar. Tidak lagi sebatas pada calon jamaah haji yang akan berangkat tahun 2020 dan 2021.

\section{Hasrat (Desire)}

Perkembangan teknologi informasi dengan kehadiran platform pesan singkat berbasis android seperti whatsapp, membuat audien dalam hal ini calon jamaah haji Kabupaten Aceh Tamiang lebih mudah menerima informasi. Seksi haji dan umrah, Kementerian Agama RI Kabupaten Aceh Tamiang, pada pase ini memahami hasrat audiens akan kebutuhan informasi yang valid. Bukan informasi keliru atau salah seperti banyak beredar di media sosial. Sehingga, Kementerian Agama RI sejak awal tahun 2020 membuat whatsapp group sebagai sarana komunikasi menjawab seluruh pertanyaan dari calon jamaah haji.

Salah seorang calon jamaah haji yang seharusnya berangkat tahun 2020, Nurlela, menyebutkan bahwa awalnya mengaku khawatir akan setoran dana haji yang telah diberikan. Apalagi, informasi yang beredar di media sosial dan sejumlah analis ekonomi yang ditulis media massa menyatakan negara krisis anggaran dan pengalihan uang haji untuk pandemi membuatnya ragu. Karena itu, setiap informasi yang diragukan ditanyakan langsung pada whatsapp group. Respon dari pengelola ibadah haji Kementerian Agama Kabupaten Aceh Tamiang memastikan bahwa uang ibadah haji masih tersedia dan bisa ditarik kapan saja. Bahkan tidak terjadi pembatalan keberangkatan sesuai kuota.

"Jadi kami menerima informasi, bahwa jika menarik uang haji. Maka akan dicoret keberangkatannya pada tahun berikutnya setelah pandemi Covid-19 berakhir. Ternyata tidak seperti itu. Kuota kita tetap bisa berangkat asal mampu melunasi lagi uang setoran ibadah haji," (Wawancara Nurlela, 20 Oktober 2021).

Hal yang sama disampaikan calon jamaah haji lainnya yaitu Samsuardi, Kelip dan Nadia. Dalam forum pertemuan tatap muka dengan Kementerian Agama RI Kabupaten Aceh Tamiang pun dijelaskan tahapan demi tahapan untuk penarikan dana ibadah haji yang telah disetorkan. Sehingga tidak ada keharusan masyarakat dan tidak ada sanksi bagi calon jamaah yang akan menarik uangnya kembali.

\section{Tindakan (Action)}

Dampak dari strategi komunikasi persuasif yang dilakukan oleh petugas haji di Kementerian Agama RI Kabupaten Aceh Tamiang, sepanjang dua tahun pandemi Covid-19, hanya satu orang yang menarik dana ibadah haji dari total 112. Hingga saat ini tercatat calon jamaah haji $(\mathrm{CJH})$ yang akan berangkat ibadah haji tahun berikutnya atau setelah pandemi hanya berjumalh 111 orang.

Strategi komunikasi persuasif, menggunakan kalimat lembut, mudah dipahami, dan dilengkapi dengan bukti berupa aturan atau kebijakan yang dikeluarkan Kementerian Agama RI menimbulkan rasa percaya (trust) dari calon jamaah haji untuk tidak menarik dana dan menunggu jadwal keberangkatan ibadah haji setelah pandemi Covid-19 berakhir. Hingga akhir penelitian ini November 2021, pandemi Covid-19 belum berakhir dan Pemerintah Arab Saudi, masih melarang pelaksanaan ibadah haji untuk seluruh negara di dunia. 


\section{Kesimpulan}

Penelitian ini menyimpulkan, strategi komunikasi persuasif petugas haji Kementerian Agama RI Kabupaten Aceh Tamiang dalam kegiatan pembatalan ibadah haji karena pandemi Covid-19 tahun 2020 dan 2021 menggunakan dua pola yaitu pertama pola tatap muka secara terbatas, dalam satu tahun dilakukan dua kali. Pola kedua yaitu lewat penggunaan aplikasi whatsapp group. Strategi persuasif dengan menggunakan bahasa Indonesia yang mudah dipahami oleh seluruh calon jamaah haji serta santun tanpa disertai ancaman atau sanksi. Komunikasi persuasif ini berdampak pada meningkatnya kepercayaan calon jamaah haji dan tidak melakukan penarikan dana ibadah haji di Kabupaten Aceh Tamiang.

Strategi komunikasi persuasif ini perlu ditingkatkan atau dibuat formulasi baku untuk seluruh struktur di Kabupaten Aceh Tamiang, hingga ke Kantor Kementerian Agama RI di seluruh kecamatan. Sehingga, informasi yang sama dapat diperoleh di tingkat kecamatan oleh seluruh masyarakat, bukan sebatas calon jamaah haji. Penyampaian pesan semakin meluas dengan kehadiran teknologi informasi. Sehingga perlu dikembangkan portal informasi dalam website Kantor Kementerian Agama RI Kabupaten Aceh Tamiang.

\section{Daftar Pustaka}

Alo liliweri. (2011). Komunikasi serba ada serba makna. Kencana.

Candrasari, S., \& Naning, S. (2019). Strategi Komunikasi Persuasif Dinas Kesehatan Kabupaten Bogor Dalam Penyuluhan Penyakit Kaki Gajah. Jurnal Bisnis Dan Komunikasi Kalbisocio, 6(1), 80-88.

Undang-Undang Republik Indonesia No. 13 tahun 2008 tentang penyelenggaraan Ibadah Haji, (2008). https://www.dpr.go.id/dokjdih/document/uu/UU_2008_13.pdf

F. Rachmadi. (1993). Public Relations Dalam Teori dan Praktek. Gramedia Pustaka Utama. Hafied Cangara. (2008). Pengantar Ilmu Komunikasi: Edisi Revisi. Raja Grafindo Persada. Hanana, A., Elian, N., \& Marta, R. (2017). Strategi Komunikasi Persuasif Dalam Menciptakan Masyarakat Sadar Wisata Di Kawasan Wisata Pantai Padang, Kota Padang. Jurnal Ilmu Sosial Mamangan, 6(1), 34-46. https://doi.org/10.22202/mamangan.v6i1.1886

Moleong, L. J. (2004). Metode Penelitian Kualitatif. Rosda Karya.

Mulyana, D. (2005). Ilmu Komunikasi: Suatu Pengantar. PT. Remaja Rosdakarya. Onong Uchjana Effendy. (2005). Ilmu Komunikasi Teori dan Praktek. Remaja Rosdakarya. Prasetyo, A. (2017). Waiting List Patterns in the Implementation of Hajj: The Fulfillment of the Rights of the Congregation (Study of Central Java Province, Indonesia). Journal of Indonesian Legal Studies JILS, 2(21), 37-42.

Sumarsono, S. (2004). Metode Riset Sumber Daya Manusia. Graha Ilmu.

Suranto AW. (2011). Komunikasi Interpersonal. Graha Ilmu.

Syaikh Abdul Aziz bin Abdullah. (2003). Tanya Jawab tentang Rukun Islam. IAIN Sumatra Utara.

Warner J. Severin dan James W. Tankard, J. (2009). Teori Komunikasi : Sejarah Metode Dan Terapan Di Dalam Media Massa. Kencana.

Wiryanto. (2004). Pengantar Ilmu Komunikasi. Grasindo.

Zain, N. L. (2017). Strategi Komunikasi Persuasif Dalam Meningkatkan Motivasi Belajar Siswa. Jurnal Nomosleca, 3(2). https://doi.org/10.26905/nomosleca.v3i2.2034 